Journal of Applied Business, Taxation and Economics Research (JABTER)

Vol. 1, No. 2, 2021 (Page: 142-157)

DOI: 10.54408/jabter.v1i2.28

e-ISSN 2808-263X

\title{
Turnaround Initiatives and Going Concern Opinion
}

\author{
Chandra Prasadhita ${ }^{*}$ \\ ${ }^{1 *}$ University of Sultan Ageng Tirtayasa, Indonesia \\ Corresponding Author: chandraprasadhita@untirta.ac.id ${ }^{1 *}$
}

Keywords: Going Concern Opinion,

Financial Distress, Turnaround Initiatives,

Positive Information.

\begin{abstract}
:
The main purpose of this study is to examine the role of Statement on Auditing Standards (PSA) No. 30 which requires an independent auditor to evaluate management actions to overcome the financial distress of the company to reduce the possibility of going concern opinion acceptance. Implementation of turnaround initiatives consists of additional capital, borrowing and debt restructuring, asset sales and cost reduction activities. The population of this research is 454 manufacturing companies listed on Indonesia Stock Exchange during 2011-2013. This study finds that borrowing and debt restructuring are positive information which reduces the probability of receiving going concern opinions. Whereas, cost reduction is the negative information that increases the probability of receiving going concern opinion. That shows there is no significant effect of withdrawal of capital and asset sales activities on the probability of going concern opinion acceptance.
\end{abstract}




\section{Introduction}

The business continuity of a problematic business entity has the potential to issue a going concern opinion by the auditor to the company. The going concern opinion issued by the auditor is bad news for the company. This opinion indicates that the company has problems regarding the sustainability of its business and could have an impact on investors' assessments. Therefore, the company certainly expects a good assessment by investors so that the company will continue.

However, the problem that often arises is that it is difficult to predict the viability of a company. This causes the auditor to experience a dilemma between morals and ethics in providing a going concern opinion. This is due to the self-fulfilling prophecy assumption which states that if the auditor gives a going concern opinion, the company will go bankrupt more quickly and will cause investors to cancel their investments or creditors to withdraw the funds needed by the company (Venuti, 2007).

Most companies that get a going concern opinion have the potential to go bankrupt. One example is happening in developed countries such as the United States. Carson, et al (2013) stated that the proportion of companies in America that are headed for bankruptcy (bankrupt firms) that have received going concern opinions seen from the level (GCO\%) is $60.10 \%$. In contrast to the proportion received by the surviving firms, which was only $15.71 \%$. The going concern opinion received by the company shows that there are conditions and events that raise the auditor's doubts about the viability of the company, both due to financial and non-financial conditions. Companies that receive a going concern opinion can result in a decrease in stock prices which means it can reduce manager performance because stock prices can be used as a tool for measuring manager performance (Jones, 1996).

Users of financial statements need information about the company's ability to continue its business (going concern) through the auditor's opinion. Going concern status determines the company's sustainability in the future. Therefore, the auditor has a responsibility to evaluate the going concern status of each client and include an explanatory paragraph in the report (Kaplan and William, 2012). Granting a company's going concern status is not an easy task carried out by the auditor. Auditors must be careful in conducting the audit process. Koh and Tan (1999) state that the absence of structured guidelines in determining going concern status makes auditors always be careful in providing going concern opinions to avoid audit failures.

Going concern opinion is often given to companies experiencing financial distress. This is because a company experiencing financial distress indicates that the company is in financial trouble including difficulty meeting liquidity, experiencing negative equity which has an impact on its business continuity. Therefore, companies in financial distress will restore the situation by making short-term and long-term efforts that can improve the company's condition (Bruynseels and Willekens, 2006).

The company's plan in overcoming financial problems that reflects the company's efforts to maintain its business continuity is one of the auditor's considerations before issuing a going concern opinion. Charmechael and Pany (1993) stated the importance of considering 
management actions in overcoming liquidity problems related to going concern problems. Therefore, this study will emphasize management actions to overcome liquidity problems in companies experiencing financial distress on the acceptance of going concern opinions.

Management as the party authorized by the principal in making strategic decisions, especially in the position of companies experiencing financial difficulties, needs to understand a business risk-based audit approach. This approach emphasizes the auditor to conduct an audit of management actions to address business risks, especially companies experiencing financial distress. The audit approach will evaluate efforts for corporate viability (strategic viability) that have a substantial impact on audit procedures. The consequences of this approach can affect the assessment of the company's financial capability in the future and can subsequently influence the audit opinion decision (Bruynseels and Willekens, 2012).

Financial recovery initiatives are company plans to overcome financial difficulties that reflect the company's efforts to maintain its business continuity (Bruynseels and Willekens, 2012). The policy contained in the Statement of Auditing Standards (PSA) Number 30 (SPAP, 2001) states that there are efforts that the company can take, namely in the form of actions in order to overcome financial distress problems that are considered by the auditor in giving a going concern opinion. These include additional capital, withdrawals or debt restructuring, asset sales, and cost reductions. This was done to overcome financial difficulties which reflected the company's efforts to maintain financial difficulties. Therefore, this study will focus on the implementation of the company's financial recovery initiatives and examine its effect on going concern opinions.

This research is based on research conducted by Bruynsels and Willekens (2012) regarding management's efforts to overcome liquidity which is divided into strategic turnaround approach and operating turnaround approach. The results show that the operating turnaround approach which consists of asset sales and cost reduction is not significant and strategic.

\section{Research Method}

This research is causality research that is research that measures the relationship between research variables. In this study, the authors conducted research using descriptive methods. The descriptive method is to provide an overview and empirical evidence with an approach to analyzing the company's annual report data. This study describes the effect of financial recovery initiatives that determine the going concern opinion.

The population in this study are manufacturing companies listed on the Indonesia Stock Exchange during 2011 - 2013. This is necessary to avoid industrial effects, namely different levels of health (Z-score). In addition, manufacturing companies are the most widely listed industry category on the IDX.

The sample in this study is a manufacturing company experiencing financial distress. This is because companies experiencing financial distress indicate companies that are headed for bankruptcy and most of these companies accept going concern opinions (Ramadhany, 2004). 
Companies experiencing financial distress (financial distress) were selected using a purposive sampling approach with the type of judgment sampling.

Logistic regression analysis was conducted to examine the factors that influence going concern opinion. Logistic regression analysis is used to test whether the probability of occurrence of the dependent variable can be predicted with the independent variable. Hypothesis testing uses logistic regression techniques to test the effect of the initiative on the possibility of receiving a going concern opinion by using the control variables of financial condition and company size. The implementation of the initiatives that will be tested include additional capital, debt and restructuring, asset sales and cost reductions.

Going concern audit opinion is a dichotomous variable and is measured using a nominal scale. Companies that receive a going concern opinion are coded 1 for an unqualified opinion with explanatory language, qualified, unqualified and not giving an opinion. Companies that receive a non-going concern audit opinion are coded 0 if the company receives an unqualified opinion (Clean opinion). This audit opinion data is presented on a nominal scale.

Additional capital in the study was measured using a dummy variable. Code 1 is a category of companies that implement the implementation of financial recovery initiatives through additional capital effectively. Code 0 is a category of companies that do not implement the implementation of financial recovery initiatives through additional capital or companies that implement the implementation of financial recovery initiatives through additional capital but are less effective. Companies that increase capital by issuing shares of at least $5 \%$ of total assets are coded 1 . Meanwhile, companies that increase capital through the issuance of shares of less than $5 \%$ of total assets are coded 0.

Debt and restructuring in this study was measured using a dummy variable by looking at the level of Debt to Equity Ratio. The company is said to be making effective debt for its financial recovery having a positive Debt to Equity Ratio with a maximum value of 3 coded 1 . Meanwhile, code 0 is given if the Debt to Equity Ratio level is negative and above the value 3 The maximum limit of the Debt to Equity Ratio value is 3 is applied in accordance with the maximum limit that is often required by creditors in providing loans.

Asset sales are carried out to increase cash or sell assets from unprofitable business units. This variable can be measured using a dummy variable. Code 1 is given if the sale of the company's non-current assets is greater than the addition of assets. Code 0 is given if the sale of the company's non-current assets is less than the addition of assets.

Cost reduction can be to save the use of cash to overcome liquidity difficulties or reduce costs to overcome losses. Cost reduction is measured using a dummy variable. Code 1 is given if the company carries out operational cost reduction activities. Code 0 is given if the company does not carry out operational cost reduction activities to overcome its financial problems.

\section{Result and Discussion}

The variable of financial condition which is proxied by the current ratio of Altman ZScore and the variable of firm size (SIZE) which is proxied by the natural log of total assets is statistically presented in table 4.5. The table provides an overview of the minimum, maximum, 
average and standard deviation. Variables of capital addition, debt and restructuring, asset sales and cost reduction are explained through the frequency table.

Table 1. Descriptive Statistics

\begin{tabular}{lrrrrr}
\hline & N & Minimum & Maximum & \multicolumn{1}{c}{ Mean } & Std. Deviation \\
\hline Financial Condition & 176 & $-13,886$ & 2,464 & 0,748 & 2,132 \\
Size & 176 & 9,267 & 18,236 & 14,135 & 1,669
\end{tabular}

Table 2. Frequency Distribution Table

\begin{tabular}{lcccc}
\hline \multicolumn{1}{c}{ Turnaround } & \multicolumn{2}{c}{ Frequency } & \multicolumn{2}{c}{ Persentage } \\
\multicolumn{1}{c}{ Initiatives } & Yes & No & Yes & No \\
\hline Additional Capital & 110 & 66 & $62,5 \%$ & $37,5 \%$ \\
$\begin{array}{l}\text { Debt and } \\
\text { Restructuring }\end{array}$ & 50 & 126 & $28,4 \%$ & $71,6 \%$ \\
Asset Sales & 160 & 16 & $90,9 \%$ & $9,1 \%$ \\
Cost Reduction & 105 & 71 & $59,7 \%$ & $40,3 \%$ \\
\hline
\end{tabular}

There are 66 companies that make good additions to capital or $37.5 \%$. On the other hand, a number of 110 companies or $62.5 \%$ did not perform capital additions properly. The data shows that only $37.5 \%$ of companies experiencing financial difficulties or experiencing financial distress made additional capital. The company's efforts to overcome financial difficulties can be done by withdrawing or restructuring debt. This is intended so that the company can pay its obligations for a longer period of time and can obtain the elimination of arrears of interest and penalties. Companies that perform debt restructuring well are 126 companies or $71.6 \%$ of the analyzed companies. In addition, a total of 50 companies or $28.4 \%$ have no indication to overcome their financial difficulties by making withdrawals or debt restructuring.

Companies experiencing financial distress can sell assets to reduce maintenance costs and capital expenditures. Therefore, the company can save cash which can then be used for the purpose of meeting the company's liquidity. The results of the frequency table show that a total of 16 companies or $9.1 \%$ of sample companies reported the sale of their assets. Companies that do not do this are 160 companies or $90.9 \%$ of the analyzed companies. Cost reduction can be done to reduce losses or save cash. Companies that reduce operating costs are 71 companies or $40.3 \%$. Companies that did not reduce costs were 105 companies or $59.7 \%$ of the analyzed companies. This shows that there is an indication that to overcome financial difficulties, most of the management carried out cost reductions.

Table 3. Hosmer and Lemeshow Test

\begin{tabular}{ccc}
\hline Chi-square & Df & Sig. \\
\hline 1,660 & 8 & 0,990 \\
\hline
\end{tabular}


Hosmer and Lemeshow's Goodness of Fit Test tests the null hypothesis that the empirical data fit or fits the model (there is no difference between the model and the data so that the model can be said to be fit). The results of the Hosmer Lemeshow fit test show that the Chi-Square is 1.660 with a df of 8 and a significance level of 0.990 . The significance level is greater than 0.05 . Therefore, the null hypothesis cannot be rejected, which means that the model can predict the value of its observations or fits the data. Therefore, it can be stated that the model is declared fit because Ho is accepted.

In addition, the Omnibus test can be used to see the feasibility of the model used by looking at the results of testing the effect of capital additions, withdrawals and debt restructuring, asset sales, cost reductions, financial condition and company size on going concern opinions simultaneously.

Descriptive statistics are used to describe the basic features of the data and provide a summary of the sample and its measurements (Mishra P, Pandey CM, Singh U, Gupta A, Sahu C, 2019).

Tabel 4. Omnibus Test

\begin{tabular}{llccc}
\hline & & Chi-square & Df & Sig. \\
\hline Step 1 & Step & 106.918 & 6 & .000 \\
& Block & 106.918 & 6 & .000 \\
& Model & 106.918 & 6 & .000 \\
\hline
\end{tabular}

The table shows the model significance value of 0.000 . Because the significance value of the model is less than 0.05 or less than 5 , then $\mathrm{HO}$ is rejected at the $5 \%$ significance level. Therefore, it can be concluded that the independent variables and control variables used in this case include capital additions, debt, asset sales, cost reductions, financial conditions, and company size together affect going concern opinions on manufacturing companies listed in BEI for the period 2011 - 2013. Therefore, the model can be said to be feasible to be used in predicting the possibility of receiving a going concern opinion.

The overall assessment of the model is done by looking at the - 2 LogL statistic. The - 2 LogL statistic is used to determine whether the model gets better if the independent variables are added. Statistical results show a model with constants only that is equal to 183.632. If the constant is added to the independent variable then $-2 \log L$ becomes 76,714 . These results indicate a $-2 \mathrm{Log} L$ decrease of 106.918. The decrease in binary logistics shows that the addition of the independent variables of additional capital, withdrawals or debt restructuring, asset sales, and cost reductions controlled by financial condition and company size makes the model better.

The Negelkerke R-square value which is interpreted as the $\mathrm{R}$ square value in multiple regression is seen to test how much influence the independent variable has on the dependent variable. The results of this study indicate the Negelkerke $R$ square value of 0.703 which means that the variables of capital addition, withdrawal and debt restructuring, asset sales and cost reduction controlled by financial conditions and company size affect the going concern opinion acceptance by $70.3 \%$. 
In addition, the value of Negelkerke R Square before adding the control variable is 0.578 (attachment 4). This shows that the ability of the independent variables consisting of capital additions, withdrawals and debt restructuring, asset sales and cost reductions can only explain the prediction of going concern opinion acceptance of $57.8 \%$. However, after the control variable the value of Negelkerke R Square increased to 0.703 (table 4.12). The test results mean that after adding the control variables in the form of financial condition and company size, the predictive ability of the implementation of financial recovery initiatives on the possibility of receiving going concern opinions becomes higher, which is $70.3 \%$.

Tabel 5. Correlation Matrix

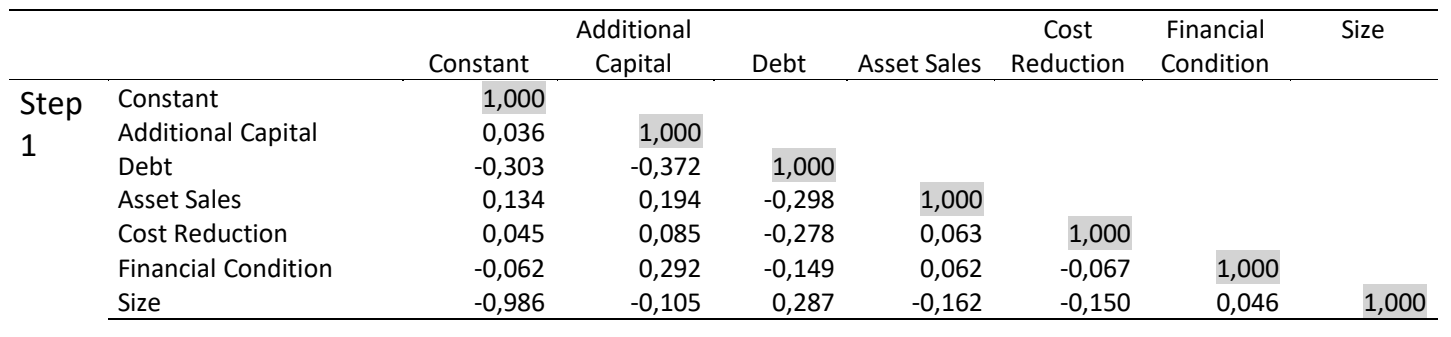

Correlation matrix between independent variables. From the following table, it can be seen that all independent variables consisting of capital additions, withdrawals or debt restructuring, asset sales and cost reductions controlled by the variables of financial condition and firm size have a correlation smaller than 0.9. The biggest correlation is found in the relationship between capital additions and debt withdrawals, which is absolute -0.372 . However, the correlation figure is still smaller than 0.90 . Thus, the correlation matrix shows that there is no correlation between independent variables or there is no multicollinearity.

Tabel 5. Logistic Regression

\begin{tabular}{|c|c|c|c|c|c|}
\hline & & B & Wald & Sig. & $\operatorname{Exp}(B)$ \\
\hline Step & Additional Capital & 1,214 & 3,312 & 0,069 & 3,367 \\
\hline \multirow[t]{6}{*}{$1^{\mathrm{a}}$} & Debt & $-3,045$ & 18,955 & 0,000 & 0,048 \\
\hline & Asset Sales & 1,693 & 2,589 & 0,108 & 5,436 \\
\hline & Cost Reduction & 2,003 & 9,720 & 0,002 & 7,410 \\
\hline & Financial Condition & $-0,286$ & 5,017 & 0,025 & 0,751 \\
\hline & Size & $-0,877$ & 12,161 & 0,000 & 0,416 \\
\hline & Constant & 10,561 & 9,805 & 0,002 & 38588,825 \\
\hline \multicolumn{2}{|c|}{ Cox \& Snell R Square } & \multicolumn{4}{|c|}{0,455} \\
\hline \multicolumn{2}{|c|}{ Nagelkerke R Square } & \multicolumn{4}{|c|}{0,703} \\
\hline & & Chi-Square & & & Sig \\
\hline \multicolumn{2}{|c|}{ Hosmer and Lemeshow Test } & \multicolumn{2}{|c|}{1,660} & 8 & 0,990 \\
\hline
\end{tabular}

The implementation of the financial recovery initiative through additional capital in manufacturing companies listed on the Indonesia Stock Exchange in 2011 - 2013 did not affect the going concern opinion. Companies that experience financial distress and make additional capital will be less likely to receive a going concern opinion. Thus, it can be said that the implementation of the financial recovery initiative by increasing the owner's capital is negative information in receiving a going concern opinion even though it has an insignificant value. 
This is related to the concept of agency relationship where managers as agents are entrusted by shareholders to make important decisions in an effort to maintain the company's business continuity. When the company experiences financial difficulties, management will make efforts to increase capital so that it has additional funds that can be used to improve liquidity positions or improve negative equity conditions to reduce auditors' doubts about the company's ability to continue its business. Furthermore, the auditor considers this as positive information in making a going concern opinion decision. Statement of Auditing Standards No. 30 (SPAP, 2001) paragraph 7 letter $d$ which states that the auditor is asked to evaluate management's plan to increase capital can be considered as positive information in making a going concern opinion decision.

The implementation of financial recovery initiatives through additional capital was not able to improve the liquidity position or improve negative equity conditions to reduce the auditor's doubts about the company's ability to continue its business. The results of this study do not support the empirical findings of Behn et al. (2001); Bruynseels and Willekens (2012) who prove that the implementation of financial recovery initiatives through additional capital reduces the possibility of receiving going-concern opinions.

The addition of capital is considered not an effective measure to maintain the viability of manufacturing companies in 2011 - 2013. This is because many manufacturing companies in 2011 - 2013 did not implement and carry out these actions properly for the company's financial recovery. It can be interpreted that the amount of additional company capital is not significant to reduce the possibility of going concern opinion. This can be caused by the difficulty of the company getting the trust of investors to increase the company's capital.

Companies experiencing financial distress can recover their finances by debt. The implementation of the financial recovery initiative through debt withdrawal is positive information in receiving a going concern opinion. This means that the implementation of financial recovery initiatives through debt withdrawal reduces the possibility of receiving a going concern opinion. The amount of the loan funds is considered to be able to overcome the problem of financial distress without ignoring the risks obtained. Therefore, the company can carry out its activities again or can settle obligations that are due.

This includes corporate debt restructuring. This action in addition to obtaining additional funds as well as debt restructuring, the company can delay payment of debts that are due and can even obtain the write-off of interest arrears (Gilson, 1990). Thus, the implementation of financial recovery initiatives through debt withdrawal can be used to overcome current financial distress. The hypothesis which states that both withdrawals and debt restructuring reduce the possibility of receiving a going concern opinion is acceptable. This means that companies that make withdrawals or good debt restructuring in companies experiencing financial distress can reduce the possibility of receiving going concern opinions.

Related to the agency concept, management mandated by shareholders as principals always tries to show good management performance through the presentation of financial statements as a form of management accountability. Companies experiencing financial distress show a signal for management to make efforts to maintain business continuity by 
withdrawing or restructuring debt by withdrawing debt or restructuring debt which can improve the company's liquidity position.

This can be explained because the borrowed funds obtained, especially for long-term debt, will be able to increase liquidity. Thus, working capital conditions will be better and can further improve the company's operational capabilities which can increase operating profit. Consistent with the empirical findings of LaSalle and Anandarajan (1996) that both withdrawal and debt restructuring by adding debt to a certain level indicate the existence of external party trust in the company or indicate management credibility which can then be considered in determining audit opinions.

The implementation of the financial recovery initiative through the sale of assets has no effect on the possibility of receiving a going concern opinion. This is because the implementation of financial recovery initiatives through the sale of assets to companies experiencing financial distress is one of the operating turnaround approaches aimed at increasing short-term profitability (Hofer, 1980). The sale of assets can generate cash while saving costs but will not be able to overcome financial distress in the next 12 months. Companies experiencing financial distress need more funds to pay maturing obligations or require more working capital from equity or debt to continue their business.

The sale of assets of companies experiencing financial distress is seen as a short-term recovery effort that is unable to provide change in the company (Schendel et al., 1976; Hofer, 1980, Barker III and Duhaime, 1997). These empirical findings also support the research of Behn et al. (2001); Bruynseels and Willekens (2012) who tested the sale of assets on the acceptance of going concern opinions the results were not significant because the test was carried out simultaneously with cost reduction and actually showed a positive regression coefficient which indicated that asset sales were negative information.

The auditor views that the implementation of the financial recovery initiative through asset sales is a short-term effort that does not guarantee the continuity of the company within the next year so that it does not reduce the auditor's doubts about the company's ability to continue its business and subsequently does not affect the acceptance of going concern opinions. This is also supported by crosstabulation data (attachment 2 ) which shows that more companies do not sell assets for financial recovery. Of the 176 sample companies, 160 companies did not sell and 16 did asset sales. Of the 38 companies that received a going concern opinion, 31 did not do so and only 7 did asset sales. Similarly, if viewed from 138 companies that received non-going concern opinions, more did not sell assets, namely 129 did not do and only 9 did.

The data above strengthens the results of logistic regression testing that asset sales do not affect the acceptance of going-concern opinions and also do not function as positive information that reduces the possibility of going-concern opinions. This is because the auditors assume that the sale of assets that are part of the operating turnaround will not be able to overcome the recovery of companies experiencing financial difficulties in the next 12 months. 
The implementation of financial recovery initiatives through cost reduction can increase the probability of receiving a going concern opinion. Cost reduction initiatives do not function as positive information (mitigating information) but instead as negative information (contrary information) that increases the possibility of receiving going concern opinions. Reducing costs actually strengthens the assumption that the company is facing a going concern problem which in the end can raise doubts about the company's ability to continue its business so that it has an impact on increasing the possibility of receiving going concern opinions.

This is because cost reduction is a company action that has a short-term impact and is unable to overcome the company's liquidity problems over the next 12 months (Bruynseels and Willekens, 2006). This is in line with the research of Geiger and Rama (2003); Bruynseels and Willekens (2006) who provide empirical evidence that cost reduction is not positive information (mitigating information) but instead increases the possibility of receiving goingconcern opinions.

This is also supported by the results of the descriptive crosstabulation (appendix 2) where companies that carry out cost reduction initiatives actually get more going concern opinions. This can be seen from 38 companies that received a going concern opinion. The companies that received the going concern opinion and made cost reductions were 29 companies (76.3\%). On the other hand, only 9 companies $(23.7 \%)$.

It can be said that companies that are experiencing financial difficulties will actually make cost reductions such as merging production area locations in one area to increase cost efficiency, reduce manpower due to the closure of factory locations or program cost reductions through restandardization of material costs, operational costs and relay out of machines. and production activities. The cost reduction is actually seen by the auditors as information indicating that the company is experiencing a going concern problem which has an impact on increasing the possibility of receiving a going concern opinion.

The company's financial condition describes the company's health level. Carcello and Neal (2000) stated that the worse the company's financial condition, the greater the probability of the company receiving a going concern opinion. Mc Keown et al (1991) found that auditors almost never give going concern audit opinions to companies that are not experiencing financial difficulties. Carcello and Neal (2000) stated that the worse the company's financial condition, the greater the probability of the company receiving a going concern opinion.

Financial condition in this study is proxied using the revised Altman Z Score (2006) bankruptcy prediction model used in Young and Wang's (2010) research. The results provide evidence that the bankruptcy prediction model as a proxy for the company's financial condition has a negative effect on the possibility of receiving a going concern opinion. These results support the findings of Ramadhany (2004) and Mutchler (1985) which state that auditors almost never issue a going concern opinion on companies that do not experience financial distress (financial distress).

Large-scale companies experiencing financial distress will find it easier to overcome their financial difficulties than small companies because large companies have stronger 
management ranks. In addition, there is a reason that the impact of large companies going bankrupt due to the self-fulfilling prophecy effect is greater than that of small companies, so the results of both studies prove that there is a significant negative effect between company scale and the acceptance of going-concern opinions (Bell and Tabor). , 1991; Mutchler 1985).

This study uses a proxy for company scale with log of total assets that has been used by previous researchers (LaSalle and Anandarajan, 1996; Anandarajan et al., 2001; Kevin et al., 2006). The use of the log of total assets is seen as representing the size of the company because it can describe the company's ability to either settle its short-term obligations with current assets or the company's ability to generate profits with its assets. Thus, large companies experiencing financial distress will find it easier to overcome their difficulties because they have greater capabilities than small companies.

\section{Conclusion}

The purpose of this study is to provide empirical evidence regarding the effect of implementing financial recovery initiatives in the form of actions taken by companies to overcome financial distress problems which become positive and negative information in receiving going concern opinions. The implementation of financial recovery initiatives through additional capital is not positive information (mitigating information) that affects the possibility of receiving going concern opinions on manufacturing companies experiencing financial distress in the 2011-2013 period. This is because it is difficult for companies experiencing financial distress to gain investor confidence to buy shares issued by companies to increase their capital so that more companies do not increase capital as an effort to recover their finances.

The implementation of financial recovery initiatives through withdrawals or debt restructuring is positive information (mitigating information) that reduces the possibility of receiving going concern opinions on manufacturing companies experiencing financial distress in the 2011-2013 period. solve the company's liquidity problems.

In this study, the implementation of financial recovery initiatives through the sale of assets is not positive information that reduces the possibility of receiving going concern opinions on manufacturing companies experiencing financial distress in the 2011-2013 period. This is because asset sales are a short-term effort for companies that have not been able to recover company finances over the next 12 months so that more companies do not take the initiative to sell assets as an effort to recover their finances.

The last measure is cost reduction. The implementation of financial recovery initiatives through cost reduction is negative information (contrary information) that increases the possibility of receiving going concern opinions on manufacturing companies experiencing financial distress in the period 2011 - 2013. This is because cost reduction initiatives actually pose additional risks for companies in carrying out their operations. Therefore, cost reduction actually indicates that the company is experiencing business continuity problems and increases the possibility of receiving a going concern opinion. 
In line with the agency concept, the manager as an agent is trusted by the principal to run the business, including taking important decisions to maintain the continuity of the company. Furthermore, company owners can monitor the implementation of company initiatives as well as evaluate management accountability by asking an independent auditor as a third party to carry out audit procedures and provide an opinion on the audit results.

This study has limitations, including: This research is limited to PSA (Statement of Auditing Standards) No. 30 which mentions the company's or client's actions to overcome financial difficulties which are only classified into capital additions, debt withdrawals, asset sales and cost reductions. This is because there are still other factors that affect the acceptance of going concern opinion only seen from the four variables. This study is only able to predict the implementation of financial recovery initiatives and the control variable on going concern opinion acceptance is $70.3 \%$. Meanwhile, the remaining $29.7 \%$ is explained by other variables outside the research model. This means that there are other variables that need to be identified to explain the going concern opinion acceptance. The measurement of the variables of the implementation of the financial recovery initiative has limitations in seeing whether the activity is actually the implementation of the company's initiative to recover its finances or whether the activity is carried out only because it is sufficient for liquidity or for other reasons.

Several limitations that affect the results of the study need to be developed in further research. Suggestions that can be submitted based on this research are as follows: Implementation of financial recovery initiatives that are oriented towards strategic approaches such as cooperation and expansion of new products or expansion of new market segments have not been tested in this study (Bruynseels and Willekens, 2012). Therefore, further research needs to be developed to examine the effect of cooperation and new products or the expansion of new market segments as positive information (mitigating information) in the acceptance of going-concern opinions. The factors that determine the going concern opinion can be grouped into four parts, namely client factors, auditors, auditor relationships with clients and the environment (Carson et al, 2013). Therefore, further research is expected not only to look at the factors that determine going concern opinions from the company or client side. Further research can be done by adding other factors that come from the auditor's side, the auditor's relationship with the client and environmental factors to explain other factors outside the research model. Measurement of the implementation of financial recovery initiatives in future research is suggested to be done by looking at the level of accuracy of these variables in order to be more accurate in explaining their effect on the possibility of receiving going concern opinions (Carson et al, 2013). Therefore, further research is recommended not only to look at the implementation of these initiatives from the notes to the financial statements. This can be useful for obtaining information on the implementation of financial recovery initiatives that are not reflected in the notes to the financial statements. 


\section{References}

Abbot, Parker dan Peters, 2003. "The Effects of Post-Bankruptcy Financing on going concern Reporting." Advances in Accounting, Vol. 20, No. 8, pp. 1-22.

AICPA. 1988. The Auditor's Considerations of an Entity's Ability to Continue as a GoingConcern. Statement on Auditing Standards No.59. Auditing Standards Board (ASB).

Arens. 2012. Auditing and assurance services: an integrated approach. Pearson Education : New Jersey.

Behn, Carcello, Hermanson dan Hermanson 1999. "Client Satisfaction and Big Six Audit Fees". Contemporary Accounting Research, Vol. 16, No.4, pp. 587-608.

Barker III, V.L.,dan Duhaime,M.L. .1997. "Strategic change in the turnaround process : theory and empirical evidence". Strategic Management Journal , Vol. 18, No. 1, pp. 13-38.

Brigham dan Houston, 2006. Dasar-Dasar Manajemen Keuangan. Jakarta: Salemba Empat.

Bruynseels dan Willekens. 2006. "Strategic Viability and Going-Concern Auidit Opinion." Marleen.willekens@econ.kuleuven.be.

2012. "The Effect Of Strategic And Operating Turnaround Initiatives On Audit Reporting For Distressed Companies." Accounting Organizations and Society, Vol. 37, No. 37, pp. 223-241.

Carcello dan Neal. 2000. "Audit committee composition and auditor reporting." The Accounting Review, Vol. 75, No. 4, pp. 453-467.

Charmechael dan Pany.(1993. Reporting on uncertainties, including going concern: The expectation gap standards proceedings of the expectation gap, roundtable. New York: AICPA.

Carson, Fargher, Geiger, Lennox, Raghunandan dan Willekens. 2013. "Audit Reporting for Going-Concern Uncertainty: A Research Synthesis." Journal of Practice \& Theory American Accounting Association, Vol. 32, No .1, pp. 353 -384.

Chen dan Church. 1996. "Going Concern Opinions and The Market's Reaction to Bankruptcy Fillings." The Accounting Review, Vol. 71. No. 1, pp. 117 - 128.

Dhillon dan Ramirez. 1998. "Debtor-in-possession financing and the resolution of uncertainty in (Chap. 11) reorganizations." Working Paper, Tulane University, New Orleans.

Elayan dan Meyer. 2001. "The impact of receiving debtor-in-possession financing on the probability of successful emergence and time spent under (Chap. 11) bankruptcy." Journal of Business, Finance and Accounting, Vol. 28, No. 7, pp. 905-942.

Eisenhardt. 1989. "Agency Theory :An Assesment and Review." Academy of Management Review, Vol. 14, No. 1, pp. $57-74$.

Ghozali Imam. 2012. Aplikasi Analisis Mutivariate Dengan Program SPSS. Badan Penerbit UNDIP : Semarang. 
Gilson. 1990. "Bankruptcy. boards. banks and bondholders-Evidence on changes in corporate ownership and control when firms default." Journal of Financial Economics, Vol. 27, pp 355-387.

Gujarati. 2008. Basic Econometrics. New York : Mc-Grawhill.

Hackenbrack, K., dan Nelson,W.M. 1996."Auditor's incentives and their application of financial accounting standards". The Accounting Review. 71 (January) : 43-59.

Hofer,C.W. 1980. "Turnaround Strategies." Journal of Business Strategy, Vol. 1, No. 1, pp. 1931.

Haron et. al. 2009. "Factors Influencing Auditors' Going Concern Opinion." Asian Academy of Management Journal, Vol. 14, No. 1, pp. 1-19.

Ikatan Akuntansi Indonesia. 2011. Standar Profesional Akuntan Publik. Jakarta: Salemba Empat.

James. 1933. "The Modern Corporation and Private Property, by Adolf A. Berle Jr. and Gardiner C. Means." Indiana Law Journal, Vol. 8, No 8, pp. 514 - 516.

Jensen dan Meckling. 1976. "Theory Of The Firm :Managerial Behavior. Agency Cost And Ownership Structure." Journal of Financial Economics, Vol. 3, No.4, pp. 305 - 360.

Jensen dan Smith. 1984. Modern Theory of Corporate Finance. New York : McGrow-Hill.Inc.

Kaplan dan William. 2012. "The Changing Relationship Between Audit firm Size And Going Concern Reporting." Accounting, Organizations and Society. Vol. 37, pp. 322-341.

Keputusan Menteri Keuangan Republik Indonesia Nomor 1002/KMK.04/1984. Tentang penentuan perbandingan antara hutang dan modal sendiri untuk keperluan pengenaan pajak penghasilan. Available at: http://www.google.co.id.

Kevin, Lam dan Mensah. 2006. “Auditor's Decision-Making Under Going-Concern Uncertaintes In Low Litigation-Risk Environments: Evidence from Hongkong." Journal of Accounting and Public Policy, Vol. 25, pp. $706-739$

Koh dan Tan. 1999. "A Neural Network Approach to the Prediction of Going concern Status." Accounting and Bussines Research, Vol. 29, No. 3, pp. 211-216.

Mutchler. 1985. "A multivariate analysis of the auditor's going concern opinion decision. Journal of Accounting Research, Vol.23, pp. 668-682.

Peraturan Menteri Keuangan Nomor: 43/KMK.017/1997. Tentang Jasa Akuntan Publik. Available at: http://www.google.co.id.

Petronela. 2004. "Perkembangan Going concern Perusahaan Dalam Pemberian Opini Audit." Jurnal Balance. 
Paquette dan Skender. 1996. "Using bankruptcy Model In The Auditing Course: The Evaluation Of Company as Going Concern. Journal Of Accounting Education, Vol. 14, No. 3, pp. 319 - 329.

Pearce II., Robinson,A.J dan Richard.B. 2003. Strategic Management : Formulation, Implementation and Control. Eight Edition. Mc.Graw-Hill Companies,Inc. New York.

Praptitorini dan Januarti. 2011. "Analisis Pengaruh Kualitas Audit. Debt Default Dan Opinion Shopping Terhadap Penerimaan Opini Going Concern." Jurnal Akuntansi dan Keuangan Indonesia, Vol. 8, No. 1, pp. $78-93$.

PSA No.30. Pertimbangan Auditor Atas Kemampuan Entitas Dalam Mempertahankan Kelangsungan Hidupnya.

Ramadhany. Alexander. 2004. "Analisis Faktor - Faktor yang Mempengaruhi Penerimaan Opini Audit Going concern pada Perusahaan Manufaktur yang mengalami Financial Distress di Bursa Efek Jakarta." Jurnal Maksi Vol 4.

Ross. 1977. The Determination of financial structure : The Incentive signaling Approach. Bell Journal of Economics 8.

Santoso dan Wedari. 2007. "Analisis Faktor - Faktor yang Mempengaruhi Kecenderungan Opini Audit dan Going concern. JAAI, Vol. 11, No. 2, pp. $141-158$.

Sawir. 2004. Analisis Kinerja Keuangan dan Perencanaan Keuangan Perusahaan. Gramedia : Jakarta.

Schendel,D.,Paton,R.G. dan Riggs,J.1976. “Corporate Turnaround Strategies: A Study of Profit Decline and Recovery". Journal of General Management, Vol.76, No.3, pp. 3-11.

Suwarsono, M. 2004. Manajemen Strategik, Konsep dan Kasus. Unit Penerbit dan Percetakan , Akademi Manajemen Perusahaan YKPN.

Setyarno dan Januarti. 2006. Pengaruh Kualitas Audit. Kondisi Keuangan Perusahaan. Opini audit tahun sebelumnya. Pertumbuhan Perusahaan terhadap Opini Going Concern. SNA 9 Padang. Agustus.

Setyowati. 2013. "Strategi Manajemen Berbasis Keuangan Sebagai Faktor Mitigasi Dalam Penerimaan Keputusan Opini Going Concern". Jurnal Ekonomi dan Bisnis, Vol. n.d, No 1, pp. $063-075$.

Swanson dan Seetharaman. 2003. The Capital Structure Paradigm. Praeger : London.

Tarigan. 2010. Values Driven Accounting (ACC V.2). Gramedia : Jakarta.

Venuti. 2007. "The Going concern Assumption Revisited Assessing a Company's Future Viability." The CPA Journal. Vol. 74, No. 5. Pp. 40-43.

Vanasco. 1994). "The Audit Committee: An International Perspective". Managerial Auditing Journal, Vol. 9, No. 8, pp. $18-42$. 
Young dan Wang. 2010. "Multi-risk level examination of going concern modifications." Managerial Auditing Journal, Vol. 25, No. 8, pp. 756 - 791.

Zhang dan Zhou. 2007. "Audit committee quality. auditor independence. and internal control weaknesses." Journal of Accounting and Public Policy, Vol. 26, pp. $300-327$. 